\title{
Quantitative Study of the Scleractinian Coral Communities of a Fringing Reef of Reunion Island (Indian Ocean)
}

\author{
C. Bouchon \\ Station Marine d'Endoume, rue de la Batterie des Lions, F-13007 Marseille, France
}

\begin{abstract}
This work was carried out on a fringing reef situated on the leeward coast (North-West) of Reunion Island (Mascarene Archipelago, Indian Ocean). A boat channel, a compact reef flat and a reef flat with transverse stripes were successively found between shore and reef front. Two structures were defined on the outer reef slope: the coral-built spurs-andgrooves zone $(0-20 \mathrm{~m})$ and the lower sloping platform, a volcanic flagstone with low biogenic coverage $(20-30 \mathrm{~m})$. Seawards, this flagstone is completely covered by a field of free organic nodules. Scleractinian coral communities were studied with quantitative sampling methods (quadrat and transect techniques) in terms of species composition, zonation and diversity patterns. On the basis of these data, the coral communities were divided into 3 assemblages: (1) A community of the boat channel and the compact reef flat. The emersion of this reef flat at low tide induces the development of facies formed by Acropora pharaonis and Pavona divaricata. The reef flat with transverse stripes appears as a transition zone with the second community. (2) A community of the spurs-and-grooves zone of the outer reef slope, divided into 3 subzones: (a) upper level, influenced by strong wave action, characterized by spatial competition between scleractinian corals and encrusting calcareous algae; (b) intermediate level dominated by a small number of Acroporid and Poritid species; (c) lower level, where the decrease in light intensity reduces the building activity of Scleractinia. (3) A community of the lower part of the outer slope, extending to the nodules field, characterized by settlement of an important number of deep species and by high species richness. 42 genera and 120 species of Scleractinia reveal a remarkable faunistic richness for the reef studied.
\end{abstract}

\section{INTRODUCTION}

The coral reefs of the Mascarene Archipelago have been ignored for a long time. The first works concerning the coral reef communities of this Archipelago were those of Baissac et al. (1962) and Pichon (1967) in Mauritius Island. Since then, Montaggioni and Faure have undertaken geological and bionomical studies of the reefs of these islands and published numerous papers (1970 to 1978). The aim of the present study is to provide quantitative, complete data on the scleractinian coral communities of one of these reefs. Moreover, this work is part of a general study of a reef including the fauna associated with corals (Ribes, 1978) and the role of boring organisms (Delacroix, unpubl.).

Reunion Island is situated in the Indian Ocean at $53^{\circ} 32^{\prime}$ East and $21^{\circ} 7^{\prime}$ South, about $800 \mathrm{~km}$ east of Madagascar (Fig. 1A) and, with Mauritius and Rodriguez Islands, constitutes the Mascarene Archipelago. Reunion Island is a relatively recently emerged volcanic island; its highest point exceeds $3,000 \mathrm{~m}$, and compared with the two other islands, is characterized by very abrupt coasts and a very narrow insular shelf. These conditions are mainly responsible for the poor development of its coral formations $\left(10\right.$ to $12 \mathrm{~km}^{2}$, com-

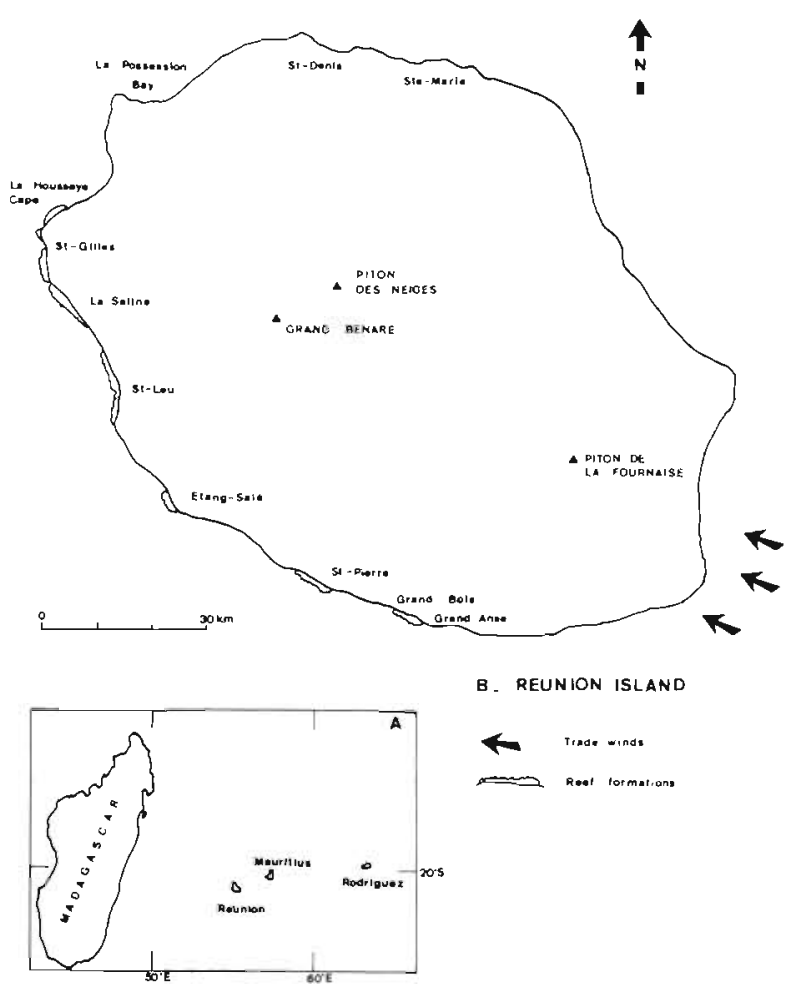

Fig. 1. (A) Location of Reunion Island in the Indian Ocean. (B) Reunion Island: location of the reefs 


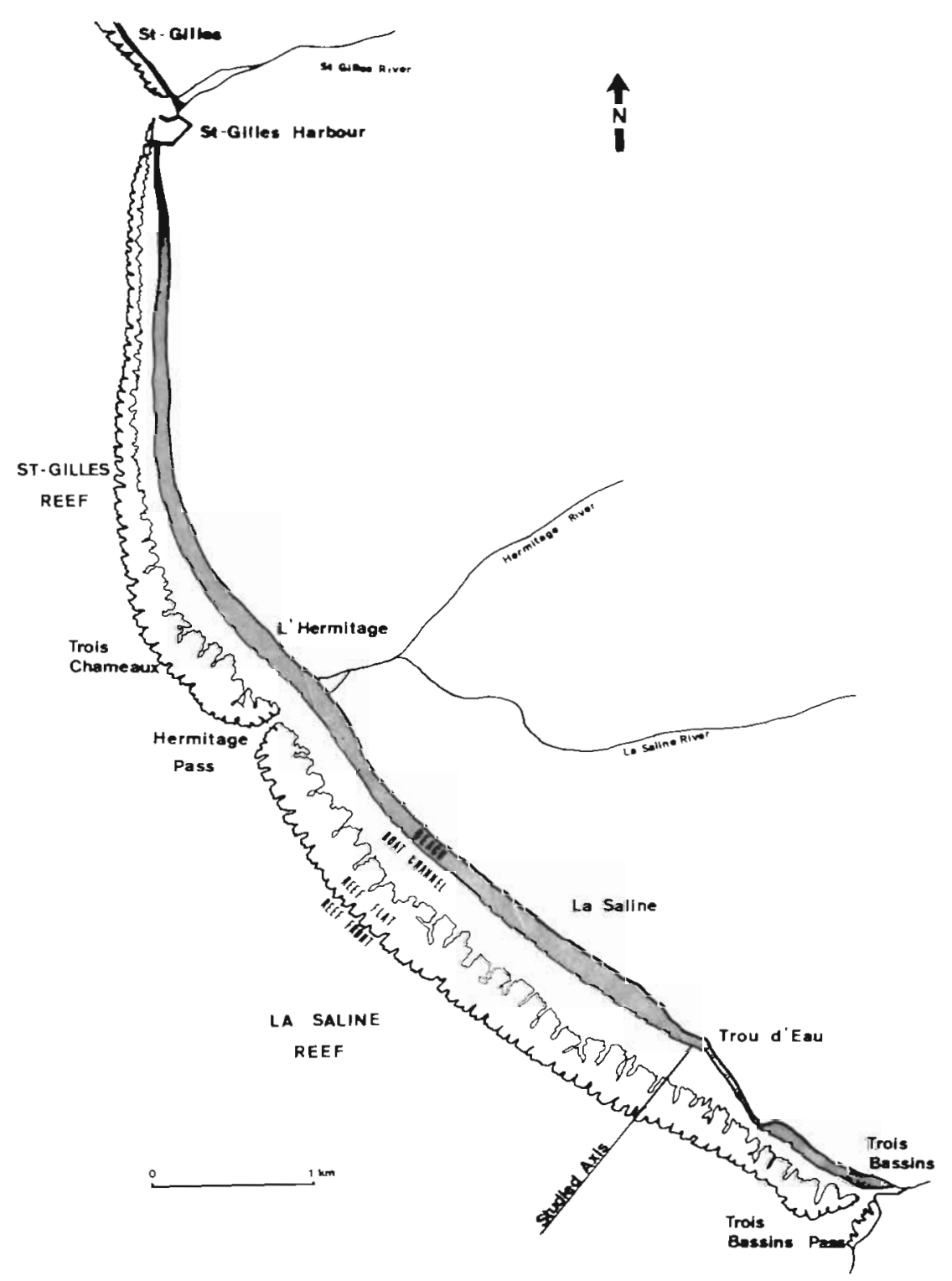

Fig. 2. The reef complex 'La Saline - St Gilles'

pared to about $200 \mathrm{~km}^{2}$ for Rodriguez Island and around $300 \mathrm{~km}^{2}$ for Mauritius Island) (Battistini, 1970; Montaggioni, 1974, 1978; Faure, 1975).

The fringing-type coral reefs are all located on the western coast of the island where they form a discontinuous belt (Fig. 1B). The coral reef complex 'La Saline-St Gilles', studied in the present paper, is the most highly developed one in Reunion Island. Located on the western coast, this reef is more than $9 \mathrm{~km}$ long and ranges in width from $50 \mathrm{~m}$ in its northern part (at $\mathrm{St}$ Gilles) to $600 \mathrm{~m}$ in the South (at La Saline) (Fig. 2). The 3 reef passes correspond to the mouths of 3 rivers: in the North, the St Gilles river created a pass, today artificially closed by the St Gilles harbour; in the middle, the Hermitage pass corresponds to the confluence of the Hermitage river and La Saline river; in the south, the Trois Bassins river gave rise to the Trois Bassins pass.

\section{THE STUDY AREA}

Due to its geographical position, Reunion Island is situated at the southern limit of the tropical zone; it is influenced by the trade winds and the south equatorial current of the Indian Ocean.

\section{Ecological Factors}

Two seasons can be distinguished: a warm season from November to December and a cold season from 
April to October. In the austral summer, the sea water temperature reaches $28^{\circ} \mathrm{C}$; it never falls below $22^{\circ} \mathrm{C}$ in winter. One-year measurements demonstrated that, in the open sea, the difference in temperature between the surface and $40 \mathrm{~m}$ never exceeded $0.5 \mathrm{C}^{\circ}$. On the reef flat, the daily variation is about 2 or $3 \mathrm{C}^{\circ}$. The salinity value is $34.7 \% \mathrm{~S}$ and does not significantly fluctuate throughout the year.

Situated on the leeward coast of the island, the reef of La Saline is protected from the direct action of the trade winds, which, however, generate on this coast, a rough, choppy sea. Moreover, the reef is often exposed to a strong oceanic surge from the South. Finally, during the austral summer, tropical cyclones develop very heavy swells. Hence the studied reef can be considered to be exposed to strong hydrodynamic forces.

Reunion Island coasts are subjected to a semi-diurnal rhythm. The maximum range during spring tides is about $0.8 \mathrm{~m}$. On the reefs, the tidal phenomenon is often hidden by meteorological factors (direction of the wind, atmospheric pressure, strong wave action). Thus the reef flat rarely emerges during low tides.

Combinations of winds, tides and swells generate very strong, irregular and poorly-known coastal currents around the island. The circulation of the water on the reef has been studied with rhodamine dyes and floats and is very similar to the pattern conceived by Faure and Montaggioni (1970) for the reef of St Pierre in the same island. The water enters the reef flat at the surf zone, flows over the reef flat towards the boat channel and returns to the open sea through the two passes.

No Secchi disc measurements could be made. As an indication, the visibility was recorded during dives; in more than $75 \%$ of the dives it exceeded $20 \mathrm{~m}$. Thus water transparency is very high.

\section{Reef Morphology}

The transect where the observations and the samplings of the present study were made, is located in an area of maximum extension of La Saline reef (Fig. 2).
The morphological structures described hereafter correspond to a cross section of the reef in this zone (Fig. 3). The reef-morphology terms used in this study were defined by Picard (1967) and Battistini et al. (1975). The horizontal part of the reef situated between surf zone and back-reef beach is more than $500 \mathrm{~m}$ wide. This zone is characterized by and hydrodynamic gradient decreasing from the surf zone to the beach. The back-reef beach, 20 to $30 \mathrm{~m}$ wide, is linked to the boat channel by a gentle slope.

The boat channel (BC in Fig. 3) is about $200 \mathrm{~m}$ wide and $1.5 \mathrm{~m}$ deep. Near the beach, the bottom consists of well-graded skeletal sediment and of dead pieces of coral near the reef flat. Scattered coral colonies and coral heads exist in the boat channel. These coral heads can anastomose to become part of the reef flat, and thus favor its extension towards the shore. Microatoll formations are rare on this reef; this is due to the low frequency of emergence of the reef flat. Some patches of sea grasses Syringodium isoetifolium occur in the northern part of the reef. Every year, these seagrass patches are damaged by cyclone surges; they seem to be in regression.

The compact reef flat (CRF) is a coral flagstone, $200 \mathrm{~m}$ wide, cut by some sandy channels which link the boat channel and the flat with transverse stripes (FTS). Seawards, the flat with transverse stripes continues the compact reef flat and is characterized by the alternation of coral ridges and surge furrows perpendicular to the shore line. This flat, located just behind the surf zone is exposed to strong hydrodynamic forces.

The reef front (RF) (or spur upper platform) constitutes the limit between reef flat and outer slope; it consists of a horizontal platform of about $20 \mathrm{~m}$ wide where the surge breaks. This platform is cut by deep channels perpendicular to the shore line connected with the grooves of the outer slope. Significantly, this reef lacks an algal reef crest and boulder track.

This type of zonation can be extended to the whole reef. However, in its northern part, the narrowness of the reef flat prevents the differentiation of such a zonation due to a hydrodynamic gradient. In this area only a small reef flat, a few meters wide, exists.

The outer reef slope can be divided into two different

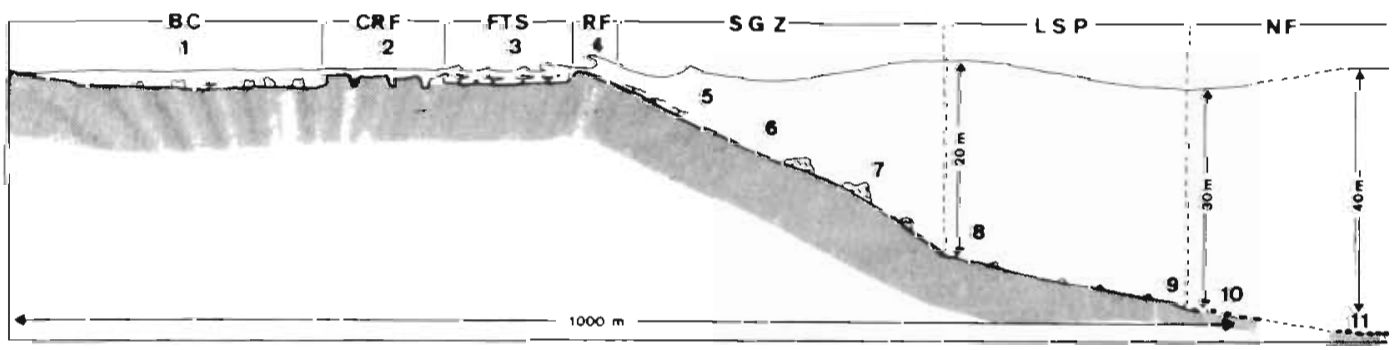

Fig. 3. Cross section of the reef in the area studied. BC: Boat channel; CRF: compact reef flat; FTS: reef flat with transverse stripes; RF: reef front; SGZ: spurs-and-grooves zone; LSP; lower sloping platform; NF: nodules field; 1 to 11: sampling stations 
areas: the spurs-and-grooves zone (SGZ) and the lower sloping platform (LSP).

The spurs-and-grooves zone constitutes the upper part of the outer reef slope and the active growing part of the reef. This zone is of biogenic origin and its morphology originates from the building activity of the scleractinian corals and calcareous algae. The spursand-grooves system stretches about $400 \mathrm{~m}$ between reef front and a depth of $20 \mathrm{~m}$. The slope is gentle and regular. The spurs-and-grooves system is typical of reefs under strong hydrodynamic activity. The alternation of spurs and grooves corresponds to preferential areas of building and erosion, respectively. Their development is maximal in shallow waters. At $5 \mathrm{~m}$, the grooves have a U-shaped section, are $5 \mathrm{~m}$ deep and 5 to $10 \mathrm{~m}$ wide, and their bottom is smooth or covered with blocks and rubble. The relief of these structures disappears progressively with increasing depth down to the lower sloping platform.

Beyond $20 \mathrm{~m}$ depth, the building activity of scleractinian corals is reduced and does not succeed in covering the volcanic bed-rock of the reef. A volcanic flagstone with scattered coral colonies occurs below the spurs-and-grooves system. At $30 \mathrm{~m}$ depth, the lower sloping platform disappears under a bed of free nodules, mainly composed of calcareous algae and encrusting foraminiferans. This nodule field (NF) slightly inclines seawards and could be observed down to $65 \mathrm{~m}$; presumably it continues beyond that depth. Such fields of rhodolith nodules were previously reported by Faure and Montaggioni (1976) and Montaggioni (1978) in the Mascarene Archipelago, by Picard (1967), Clausade et al. (1971), Thomassin (1971), Pichon (1973) and Weydert (1974) at Tulear (Madagascar), and by Barnes et al. (1971) at Aldabra.

Taking into account some local variations, the morphological structures of the outer slope of La Saline reef can be extended to the whole Mascarene Archipelago (Faure, 1975; Pichon, 1971) and in Madagascar as well, on the reef of Tulear (Picard, 1967; Clausade et al., 1971).

\section{MATERIALS AND METHODS}

\section{Sampling Methods}

The distribution of scleractinian corals has been studied quantitatively on a cross section of the reef mentioned above. A review of the quantitative studies of coral communities existing in literature shows that mainly two kinds of recording methods have been used by different authors: the quadrat method (e.g. Davies et al., 1971; Salvat, 1972; Laxton and Stablum, 1974; Maragos, 1974; Morton, 1974; Maragos and Jokiel,
1976; Neudecker, 1976; Dinezen, 1977; Ott and Auclair, 1977) and the transect method (Loya and Slobodkin, 1971; Loya, 1972, 1976a, b; Porter, 1972a, b; Done, 1977 and Ditlev, 1978). Several authors (Stoddart, 1971; Loya, 1973; Maragos, 1974) agree that standardisation in sampling technology is lacking, but until now no attempt to compare effectively the efficiency of the different methods in the field has been made. Hence during data collection a quadrat recording technique and a transect technique were used simultaneously to provide comparative data by both methods. This comparative study forms the subject of other papers (Bouchon, 1978; Bouchon, unpubl.) hence this methodology will be described here only briefly.

The quadrat technique derives from the method of Maragos and Jokiel (1976). The quadrat is constituted by a $1 \times 1 \mathrm{~m}$ plastic frame on which a network of strings delimits 100 squares of $100 \mathrm{~cm}^{2}$. The quadrat is fixed to the bottom. The surface of the vertical projection of each large colony is estimated to half of the size of the mesh $\left(50 \mathrm{~cm}^{2}\right)$. The small colonies, the projected surface of which is less than $100 \mathrm{~cm}^{2}$, are entirely collected and their surface is later measured to $10 \mathrm{~cm}^{2}$. The possible presence of other colonies beneath the main colony is checked. A sample is taken and labelled for identification. Other information, such as the nature of the substratum, its coverage with other organisms (algae, soft corals, sponges) and all data concerning the associated fauna are also recorded. Once the sampling is completed, the frame is removed and sampling is repeated until the minimum area for the studied biota has been reached.

The line transect technique used is similar to the method of Loya and Slobodkin (1971) and Loya (1972). The instrument employed is a $10 \mathrm{~m}$ long tape-measure tensioned between two pegs. The transect is run parallel to the shore line in order to maintain the homogeneity of ecological conditions all along the survey. Any coral colony underlying this line transect is recorded and its size, measured to the nearest $\mathrm{cm}$, is directly read from the tape. Samples are taken for identification and complementary information is noted as in the quadrat method. Once the recording of the first transect is completed, the site of the tape measure is changed, and new surveys are carried out to cover the minimum sampling length.

\section{Location of Sampling Stations}

The recordings were carried out at 11 stations distributed along an axis perpendicular to the shore line (Fig. 3). The stations in the boat channel and on the reef flat were located in the different morphological zones suspected to form separate biota: Station 1 was 
located in the middle part of the boat channel, Station 2 on the compact reef flat, Station 3 on the reef flat with transverse stripes and Station 4 on the reef front (surf zone). On the outer slope, the stations were distributed down to $30 \mathrm{~m}$ according to depth (Station 5: $5 \mathrm{~m}$; Station 6: $10 \mathrm{~m}$; Station 7: $15 \mathrm{~m}$; Station 8: $20 \mathrm{~m}$; Station 9: $30 \mathrm{~m}$ ). Station 9 was located at $30 \mathrm{~m}$, i.e. at the end of the lower sloping platform. Station 10 was also situated $30 \mathrm{~m}$ deep but in the field of nodules. Station 11 was placed at $40 \mathrm{~m}$, also in the field of nodules. In addition, qualitative observations were made to a depth of $60 \mathrm{~m}$.

\section{Data Processing}

From the data obtained by both methods, 3 information indices were directly calculated: (1) The coverage of the substratum $(\mathrm{S} \%)$ :

$$
\mathrm{S} \%=\frac{\text { total size of colonies }}{\text { total surface (quadrats) or length (transects) recorded }} \times 100
$$

The sizes of the colonies are expressed in surface area measures (quadrat method) and, with the transect method, in length measures (diameter of the colonies).

(2) The dominance of colonies (in number) of each species:

for Species $\mathrm{A}=\frac{\text { number of colonies of } \mathrm{A}}{\text { total number of colonies }} \times 100$

(3) The dominance in size of each species:

for Species $A=\frac{\text { total of the sizes of colonies } A}{\text { total covering by Scleractinia }} \times 100$

The results obtained by both techniques lend themselves to statistical analysis and have been compared using a Spearman test (Bouchon, 1978; Bouchon, unpubl.). No statistically significant difference between the two methods was found; hence the data were combined.

On the whole, 4350 coral colonies were measured

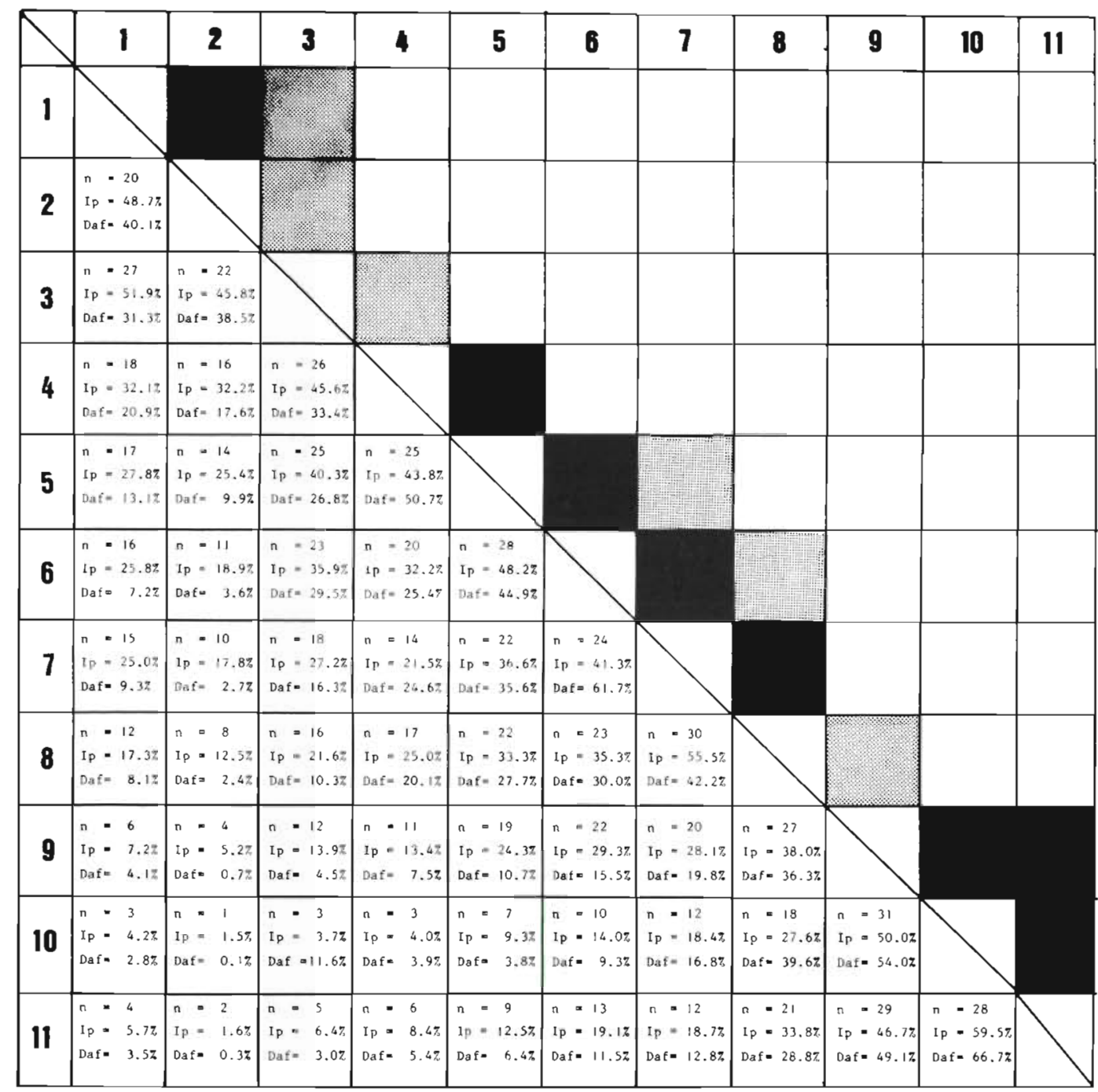

Fig. 4. Degree of affinity between the different stations. n: number of common species; Ip: Jaccard index; Daf: Sanders index 
and studied. From this data, two ecological indices were computed: the Shannon index $\left(\mathrm{H}^{\prime}\right)$, representative of the degree of structuring of a community and the Pielou's evenness index $\left(\mathrm{J}^{\prime}\right)$ which is more useful than the Shannon index for comparing communities different in species richness.

To separate the different communities, the degree of affinity between different stations was studied, computing coefficients of affinity. The simplest index of affinity is the number of common species for two stations. The community index of Jaccard (Ip) derives directly from this notion (Jaccard, 1902):

$$
\mathrm{Ip}=\frac{\text { number of common species at the two stations }}{\text { total number of species at the two stations }} \times 100
$$

This coefficient, essentially of qualitative significance, fluctuates between $0 \%$ (no common species) and $100 \%$ (identity of faunistic lists). The degree of affinity of Sanders (Daf.) is founded on a more quantitative comparison (Sanders, 1969). Considering the lists of species for the two stations (A and B), each species common to the two stations is characterized by a pair of numbers ( $\mathrm{Pi} \mathrm{A}$ and $\mathrm{Pi} \mathrm{B}$ ) representing the dominances of this species in the two stations. The Sanders' coefficient is the sum of the lowest dominance numbers for all the common species:

$$
\text { Daf. }=\sum_{i=1}^{1=S} \text { inf. (Pi A, Pi B). }
$$

where $\mathrm{S}=$ number of species common for the 2 stations. The degree of affinity fluctuates between $0 \%$ (no common species) to $100 \%$ (identity of faunistic list and identity of dominances of each species at the 2 stations). From these 3 coefficients, a square matrix for the 11 stations was drawn (Fig. 4).

\section{RESULTS}

A total of 120 species belonging to 42 genera were collected on the reef studied (Table 1). The affinity coefficients between the stations are shown in Figure 4. Three groups of stations can be distinguished: a first group constituted by the stations of the boat channel and the reef flat (Stations 1 and 2); a second group including the stations of the outer slope from the reef front to $20 \mathrm{~m}$ deep (Stations 4 to 8 ); a third group combining the 3 stations located between 30 and $40 \mathrm{~m}$ (Stations 9, 10, 11). These groups of stations are separated by areas where the affinity indices are lower. They correspond to transition zones: the reef flat with transverse stripes (between compact reef flat and reef front) and a zone, between 20 and $30 \mathrm{~m}$ deep separating the 2 groups of stations of the outer slope. All the data concerning this quantitative study, too numerous to be included here, can be found in Bouchon (1978) or obtained from the author.
Three different communities of Scleractinia were found on the reef of La Saline: a community of the boat channel and the reef flat, another one characterizing the spurs-and-grooves zone and a deep community settled on the lower sloping platform and the nodules field. The features of these different communities will later be successively studied.

\section{Community of the Boat Channel and Reef Flat}

The boat channel and the reef flat are characterized by a progressive decrease in wave energy towards the shore, high light intensity and, for the reef flat, periodic emersions. The coral community of both zones includes a large stock of typical species: Psammocora contigua, Stylocoeniella armata, Acropora pharaonis, Montipora circumvalata, Pavona cactus, $P$. decussata, $P$. divaricata, $P$. frondifera, Cyphastrea microphthalma and the hydrocorallia Millepora exaesa. These species are dominant in the community (dominance $50 \%$ ) and do not appear on the outer reef slope. However, the greatly differing morphologies of these 2 areas involve particular aspects of the community which are worth examining separately.

\section{Boat Channel}

The scarcity of hard substrates, the absence of emergence and currents paralleling the shore line characterize this area. The coverage by sessile organisms increases from the shore to the reef flat, but remains very low ( 4 to 5 by sponges and $2.5 \%$ by Scleractinia); 35 species of corals were collected. The Shannon index is low ( $\mathrm{H}^{\prime}=3.43$ bits ind.) as is the Pielou index $\left(\mathrm{J}^{\prime}=0.67\right)$. This is due to the fact that only 4 species constitute more than $65 \%$ of the community by their dominance in number of colonies and their coverage dominance:

$\begin{array}{lcc} & \% \text { n of } & \% \\ & \text { colonies } & \text { coverage } \\ \text { Pocillopora damicornis bulbosa } & 30 \% & 15 \% \\ \text { Montipora circumvallata } & 18 \% & 31 \% \\ \text { Acropora pharaonis } & 9 \% & 11 \% \\ \text { Porites (P.) nigrescens } & 11 \% & 8 \% \\ \text { Total } & 68 \% & 65 \%\end{array}$

Three species are characteristic of the boat channel only: Pocillopora damicornis $f$. bulbosa, which is typical of sheltered zones and shallow waters, Pavona cactus and the fire coral Millepora exaesa. These sheltered conditions promote the settlement of some species usually belonging to the deep community of the outer reef slope (Leptastrea bottae, L. transversa). 
Table 1. Distribution of the species on the reef

\begin{tabular}{|c|c|c|c|c|c|c|c|c|c|c|c|}
\hline \multirow[t]{2}{*}{ Species } & \multicolumn{11}{|c|}{ Stations } \\
\hline & 1 & 2 & 3 & 4 & 5 & 6 & 7 & 8 & 9 & 10 & 11 \\
\hline Psammocora contigua (Esper, 1797) & + & + & $t$ & + & & & & & & & \\
\hline P. explanulata Van der Horst, 1922 & & & & & & & & & & + & \\
\hline P. haimeana Milne-Edwards \& Haime, 1851 & & & & & & + & + & + & & & \\
\hline P. nierstraszi Van der Horst, 1921 & & & & & & & & & + & + & \\
\hline P. profundacella Gardiner, 1898 & + & & & & + & + & + & + & + & & \\
\hline Stlylophora pistillata (Esper, 1797) & & & & & & & & & + & & \\
\hline S. Mordax (Dana, 1846) & & & & & + & & & & & + & \\
\hline S. mordax forma compressa & & & & & & & & & + & & + \\
\hline Pocillopora damicornis forma bulbosa (Linnacus, 1758) & + & & & & & & & & & & \\
\hline P. damicornis forma brevicornis & + & + & + & + & + & + & + & + & & & \\
\hline P. damicornis forma setchelli & & & & + & + & + & & & & & \\
\hline P. damicornis forma caespitosa & & & & & & & + & + & + & + & + \\
\hline P. eydouxi Milne-Edwards \& Haime, 1860 & + & & + & & & + & + & + & & & \\
\hline P. verrucosa (Ellis \& Solander, 1786) & + & & + & + & + & + & + & + & + & & \\
\hline Stylocoeniella armata (Ehrenberg, 1834) & + & & & & & & & & & & \\
\hline S. guentheri Basset-Smith, 1890 & & & & & & & & & & & + \\
\hline Acropora calamaria mamillata (Brook, 1892) & & & & & + & & & & & & \\
\hline A. cerealis (Dana, 1846) & + & & + & & & & & & & & \\
\hline A. clathrata (Brook, 1891) & & & & & & + & + & & + & & \\
\hline A. cytherea (Dana, 1846) & & & + & & & & & & & & \\
\hline A. danai (Milne-Edwards \& Haime, 1860) & + & + & + & + & + & + & + & + & & & \\
\hline A. digitifera (Dana, 1846) & + & + & + & + & + & + & & & & & \\
\hline A. granulosa (Milne-Edwards \& Haime, 1860) & & & & & & & & & + & + & + \\
\hline A. hemprichi (Ehrenberg, 1832) & & + & + & & + & + & + & & & & \\
\hline A. humilis (Dana, 1846) & + & & + & + & + & + & + & & & & \\
\hline A. palmerae Wells, 1954 - A. robusta (Dana, 1846) & + & & & + & + & & & & & & \\
\hline A. pharaonis (Milne-Edwards \& Haime, 1860) & + & + & + & & & & & & & & \\
\hline A. polystoma (Brook, 1891) & & & & & + & & & & & & \\
\hline A. pulchra (Brook, 1891) & + & + & + & + & & & & & & & \\
\hline A. surculosa (Dana, 1846) & & & & & + & + & + & & & & \\
\hline A. valida (Dana, 1846) & & & + & + & + & + & + & + & + & & \\
\hline A. variabilis (Klunzinger, 1879) & + & + & + & + & + & + & + & + & & & \\
\hline A. $\mathrm{sp} . \times$ & + & + & + & + & + & & + & & & & \\
\hline Astreopora horizontalis Bernard, 1896 & & & & & & & + & & + & + & \\
\hline A. incrustans Bernard, 1896 & & & & + & & + & & + & + & & + \\
\hline A. myriophthalma (Lamarck, 1816) & & & + & & + & + & + & + & + & + & + \\
\hline A. ocellata Bernard, 1896 & & & & & & & & + & + & & \\
\hline Montipora circumvallata (Ehrenberg, 1834) & + & + & + & & & & & & & & \\
\hline M. edwardsi Bernard, 1897 & + & & + & & & & & & & & \\
\hline M. erythraea Von Marenzeller, 1906 & & & + & + & + & & & & & & \\
\hline M. informis Bernard, 1897 & + & & + & & & + & & & & & \\
\hline M. solanderi Bernard, 1897 & & & + & + & + & & & & & & \\
\hline M. subtilis Bernard, 1897 & & & & & & + & & & + & + & + \\
\hline M. tuberculosa (Lamarck, 1816) & & & + & & + & & & + & + & + & + \\
\hline M. venosa (Ehrenberg, 1834) & & + & & & + & + & & + & t & & \\
\hline M. verrucosa (Lamarck, 1816) & & & & & & & & & + & + & \\
\hline M. sp. 1 & & & & + & + & + & + & & & + & \\
\hline M. sp. 2 & & & & & & & & & & & + \\
\hline M. sp. 4 & & & & + & & & & + & + & + & + \\
\hline Pavona cactus (Forskäl, 1775) & + & + & & & & & & & & & \\
\hline P. clavus (Dana, 1846) & & & & + & + & & & + & & & \\
\hline P. decussata (Dana, 1846) & + & + & + & & & & & & & & \\
\hline P. divaricata (Lamarck, 1816) & + & + & + & & & & & & & & \\
\hline P. explanulata (Lamarck, 1816) & & & & & & & & + & & & \\
\hline P. frondifera Lamarck, 1816 & & + & & & & & & & & & \\
\hline P. maldiviensis (Gardiner, 1905) & & & & & & & & & & + & \\
\hline P. (Polyastrea) obtusata & & + & & + & & & & & & & \\
\hline P. varians Verrill, 1864 & + & + & + & + & + & & + & + & & & \\
\hline Leptoseris fragilis Milne-Edwards \& Haime, 1849 & & & & & & & & & & & + \\
\hline L. hawaiensis Vaughan, 1907 & & & & & & & & & & & + \\
\hline L. incrustans (Quelch, 1886) & & & & & & & & & + & + & + \\
\hline L. mycetoseroides Wells, 1954 & & & & & & & & & + & + & + \\
\hline Gardineroseris planulata (Dana, 1846) & & & & & & & + & & & & \\
\hline Pachyseris speciosa (Dana, 1846) & & & & & & & & & + & & \\
\hline
\end{tabular}


Table 1 Distribution of the species on the reef (continued)

\begin{tabular}{|c|c|c|c|c|c|c|c|c|c|c|c|}
\hline \multirow[t]{2}{*}{ Species } & \multicolumn{11}{|c|}{ Stations } \\
\hline & 1 & 2 & 3 & 4 & 5 & 6 & 7 & 8 & 9 & 10 & 11 \\
\hline Coscinarea monile (Forskäl, 1775) & & & & & & & + & + & + & + & + \\
\hline Horastrea indica Pichon., 1971 & & & & & & & & & + & + & + \\
\hline Cycloseris patelliformis (Boschma, 1923) & & & & & & & & & + & + & + \\
\hline C. vaughani (Boschma, 1923) & & & & & & & & + & & & \\
\hline Fungia (Pleuractis) scutaria Lamarck, 1801 & & & & & & & + & + & + & & + \\
\hline F. (Pleuractis) paumotensis Stuchburry, 1833 & & & & & & & & & + & + & \\
\hline Fungia sp. (juveniles) & & & & & & & + & & + & + & \\
\hline Herpolitha limax (Esper, 1797) & & & & & & & & & + & & \\
\hline Porites (Porites) lutea Milne-Edwards \& Haime, 1851 & + & + & + & + & + & + & + & + & + & + & + \\
\hline P. (Porites) nigrescens Dana, 1846 & + & + & + & + & + & + & & & & & \\
\hline P. (Porites) solida (Forskäl, 1775) & + & + & + & + & + & + & + & + & + & & \\
\hline P. (Synarea) iwayamaensis Eguchi, 1938 & + & + & + & + & & & & & & & \\
\hline Porites sp. & & & & + & & & & & & & \\
\hline Goniopora gracilis (Milne-Edwards \& Haime, 1860) & & & & + & & & & + & & + & + \\
\hline G. Iobata Milne-Edwards \& Haime, 1857 & & & & + & & & & + & & & \\
\hline G. mauritiensis prima Bernard, 1903 & & & + & + & & & & & & & \\
\hline G. tenuidens (Quelch, 1886) & & & & & & & & & & + & + \\
\hline Alveopora fenestrata Lamarck, 1816 & & & & & + & & & & & & \\
\hline Plesiastrea versipora (Lamarck, 1816) & & & & & & & & & + & & \\
\hline Favia favus (Forskäl, 1775) & & & + & & + & + & + & + & + & & \\
\hline F. matthai Vaughan, 1918 & & & & & & & & & & + & + \\
\hline F. pallida (Dana, 1846) & & & & & + & + & & + & + & + & + \\
\hline F. rotumana (Gardiner, 1899) & & & & & + & & & & & & \\
\hline F. speciosa (Dana, 1846) & & & & & & + & + & + & + & + & + \\
\hline F. stelligera (Dana, 1846) & & & + & + & + & + & & & & & \\
\hline Favia (juveniles) & & & & & + & + & & + & + & + & + \\
\hline Favites abdita (Ellis \& Solander, 1786) & & & & & + & + & & & & & \\
\hline F. complanata (Ehrenberg, 1834) & & & & & + & & & & & & \\
\hline F. flexuosa (Dana, 1846) & & & & & & + & + & + & & & \\
\hline F. pentagona (Esper, 1794) & + & & & & + & $-t$ & + & + & + & + & + \\
\hline F. peresi Faure \& Pichon, 1978 & & & & & & & & + & + & + & + \\
\hline Favites sp. (juveniles) & & & & & & & & & + & + & \\
\hline Goniastrea palauensis (Yabe, Sugiyama \& Eguchi, 1936) & & & & & & & & + & + & + & \\
\hline G. pectinata (Ehrenberg, 1834) & & & & & & & + & + & & + & + \\
\hline G. retiformis (Lamarck, 1816) & & & & & + & & & & & & \\
\hline Caulastrea tumida Matthai, 1928 & & & & & & & & & + & + & + \\
\hline Oulophyllia crispa (Lamarck, 1816) & & & & & & & & + & & & + \\
\hline Platygyra daedalea (Ellis \& Solander, 1786) & + & & + & + & + & + & + & + & & & \\
\hline P. daedalea forma astreiformis & & & & & & & + & + & + & & + \\
\hline Leptoria phrygia (Ellis \& Solander, 1786) & & & + & + & & + & & & & & \\
\hline Hydnophora exesa (Pallas, 1766) & & & & & & & & & + & & \\
\hline H. microconos (Lamarck, 1816) & + & & + & t & + & + & + & + & + & & \\
\hline Montastrea annuligera (Milne-Edwards \& Haime, 1849) & & & + & & + & + & & + & + & & \\
\hline Leptastrea bottae (Milne-Edwards \& Haime, 1849) & + & & & & & & & & & + & \\
\hline L. purpurea (Dana, 1846) & & & + & & & & & & & & \\
\hline L. transversa Klunzinger, 1879 & + & & & & & & + & + & & & \\
\hline Cyphastrea microphthalma (Lamarck, 1816) & + & + & + & & & & & & & & \\
\hline C. serailia (Forskäl, 1775) & & & & & & + & + & + & + & + & + \\
\hline Echinopora gemmacea (Lamarck, 1801) & & & & + & + & + & + & + & & & \\
\hline Galaxea fascicularis (Linnaeus, 1767) & & + & + & + & + & + & + & + & & & \\
\hline Acanthastrea echinata (Dana, 1846) & & & & & & + & + & + & + & + & + \\
\hline Parascolymia sp. & & & & & & & & & + & + & + \\
\hline Echinophyllia aspera Ellis \& Solander, 1786 & & & & & & & + & + & & & + \\
\hline Gyrosmilia interrupta (Ehrenberg, 1834) & & & & & & & & & + & & \\
\hline Turbinaria irregularis Bernard, 1896 & & & & & & & + & + & + & + & + \\
\hline$T$ mesenterina (Lamarck, 1816) & & & + & + & & & & & & & \\
\hline$T$ peltata (Esper, 1797) & & & & & & & & & + & + & + \\
\hline Millepora exaesa Forskäl, 1775 & + & + & + & & & & & & & & \\
\hline M. platyphylla Ehrenberg \& Hemprich, 1834 & & & & + & + & + & & & + & & \\
\hline M. tenera Boschma, 1949 & + & + & + & + & + & & & & & & \\
\hline Alcyonarians & & & & & + & + & + & + & + & & \\
\hline
\end{tabular}


In the boat channel, a strong competition for colonization of the hard substrate has existed for a few years between the scleractinian corals and a sponge (belonging to the genus Cliona) which has occupied $50 \%$ of the substrate available. The appearance of this sponge is probably due to an increase in organic material in the boat channel resulting from a recent urbanisation of the coast. The transition between the boat channel and the compact reef flat is characterized by an increase in coral coverage. The anastomosis of these colonies contributes to the growth of the reef flat towards the shore.

\section{Compact Reef Flat}

The compact reef flat is a coral-built flagstone, intersected by sandy channels, periodically subjected to emersion. The most important feature of this zone is the appearance of a facies due to Acropora pharaonis and Pavona divaricata. The exuberant growth of these two species contributes to the formation of supracolonies able to cover several tens of square meters. This results in a mosaic pattern in the community. Approximately one third of the colonized surface of the reef flat is occupied by a monospecific settlement of Acropora pharaonis, one third by a monospecific of Pavona divaricata and the remaining part by a more diversified community (24 species found). The coral coverage rate is about $50 \%$. The values of the Shannon index and the Pielou evenness index for the diversified community are respectively: $\mathrm{H}^{\prime}=3.36$ bits ind. and $\mathrm{J}^{\prime}$ $=0.73$. Taking into account the presence of the monospecific areas, these values decrease $\left(\mathrm{H}^{\prime}=2\right.$ bits ind. and $J^{\prime}=0.5$ ). Three species dominate the polyspecific zones:

\section{Acropora pharaonis Montipora circumvallata Pavona divaricata Total}

$\begin{array}{cc}\% \text { n of } & \% \\ \text { colonies } & \text { coverage } \\ 13 \% & 28 \% \\ 22 \% & 19 \% \\ 18 \% & 21 \% \\ 53 \% & 68 \%\end{array}$

The presence of a facies with Acropora and Pavona is probably related to the severe ecological conditions of the compact reef flat (periodical emergence and desiccation of coral colonies). In the boat channel, in spite of the scarcity of hard substrates, less harsh ecological conditions favour the settlement of more species (35 species in the boat channel and 24 on the reef flat).

Moreover, the edges of the surge channels cutting the reef flat are principally occupied by the Hydrocorallia Millepora tenera which also forms a facies. According to Pichon (1973), this species can be considered as indicator of moderate hydrodynamic action.

\section{Reef Flat with Transverse Stripes: A Transition Zone}

The reef flat with transverse stripes, located just behind the reef front is generally submitted to strong wave action and sometimes, during spring tides, to emergence. The coral community of this area has no proper individuality and its species belong to both the community of the reef flat and that of the upper part of the outer slope. However, the scleractinian Turbinaria mesenterina can be considered characteristic of this zone; $69 \%$ of the substratum is covered with corals, the remaining part being occupied completely by calcareous red algae (Porolithon sp. and Peyssonnelia sp.) which proliferate in this wave exposed area; 42 species of Scleractinia were collected. A high value of the Shannon index $\left(\mathrm{H}^{\prime}=4.26\right.$ bits ind.) is due to the great species richness of this intermingling zone of two communities. The Pielou evenness index, which indicates the degree of structuring of a community, is comparable to that of the preceding zones $\left(\mathrm{J}^{\prime}=0.79\right)$. The reef flat with transverse stripes is characterized by a facies of Acropora danai. A similar facies with Acropora danai also exists on the outer reef slope at $10 \mathrm{~m}$. This species can be considered as indicator of moderate wave action but disappears in very exposed area (reef front). Three species are dominant in this zone:

$\begin{array}{cc}\% \text { n of } & \% \\ \text { colonies } & \text { coverage } \\ 15 \% & 38 \% \\ 12 \% & 9 \% \\ 16 \% & 16 \% \\ 43 \% & 63 \%\end{array}$

Acropora danai

Montipora circumvallata

Porites (Synarea) iwayamaensis

Total

$43 \% \quad 63 \%$

Porites (Synarea) iwayamaensis is widely distributed from the boat channel (sheltered area) to the reef front (exposed zone) but totally disappears on the outer reef slope. Hence it appears to require shallow water with strong illumination.

In the northern part of the studied reef, the boat channel tends to disappear, the reef flat is very narrow ( $50 \mathrm{~m}$ wide) and wave action is thus more important. Species dominant in this area belong to the outer-slope community.

\section{Community of the Spurs-and-grooves Zone}

The spurs-and-grooves zone corresponds to the 'frontorecifal' division of Picard (1967), Clausade et al. (1971), Pichon (1973), Battistini et al. (1975) and to the 'morphorecifal' zone of Faure and Montaggioni (1970, 1976). Characteristic species for this area are difficult to distinguish. The community is mainly constituted by widely distributed species, tolerant to varied ecological conditions: Pocillopora damicornis forma brevicor- 
nis, $P$. eydouxi, $P$. verrucosa, Acropora variabilis, Astreopora myriophthalma, Pavona varians, porites (P.) lutea, P. (P.) solida, Platygyra daedalea, Hydnophora microconos, Montastrea annuligera and Galaxea fascicularis. Moreover, on the studied reef, some species have a distribution restricted to the spurs-and-grooves zone: Psammocora haimeana, $P$. profundacella, Acropora valida, Favia favus and Echinopora gemmacea. According to particular ecological conditions and with respect to the abundance-dominance relations, it is possible to discern in this community an upper level (from 0 to $5 \mathrm{~m}$ ), an intermediate level (between 5 to $20 \mathrm{~m}$ ) and a lower level (from 20 to $25 \mathrm{~m}$ ).

\section{Upper Level $(0-5 \mathrm{~m})$}

Emersion during low spring tides of the spurs' upper platform and strong wave action are the main ecologi cal factors in this area. This zone is characterized by strong competition between scleractinian corals and encrusting red algae (coverage by Scleractinia: $40-50 \%$; coverage by red algae: $50-60 \%$ ). The community comprises species adapted to strong wave action (massive and encrusting forms or short, branched colonies); 42 species were collected on the spurs. The Shannon index ( $\mathrm{H}^{\prime}=4.50 \mathrm{bits}$ ind.) and the Pielou evenness index $\left(\mathrm{J}^{\prime}=0.85\right)$ reveal a high structuring of the community. Species representing more than $50 \%$ of this community are: Acropora digitifera, A. danai, A. palmerae, A. robusta. Favia stelligera, Goniastrea retiformis and the Hydrocorallia Millepora platyphylla. Some species indicatory of wave-exposed areas are typical of this level: Pocillopora damicomis forma setchelli, Acropora calamaria, A. palmerae, A. robusta (these Acropora colonies have encrusting shaped forms), Favia stelligera, Goniastrea retiformis and mainly the fire coral Millepora platyphylla which form a facies on the reef front. The vertical walls of the spurs were only studied from a qualitative point of view. These walls are essentially colonized by massive or encrusting forms: Pavona varians, Porites (P.) lutea, Porites (P.) solida, Favia pallida, Favites abdita, PlatyGyra daedalea, Monstastrea and Echinopora gemmacea. Under overhangs appear Stylasteridae belonging to the genus Distichopora (Distichopora violacea and Distichopora sp.). The bottoms of the grooves are encumbered by blocks and pebbles made unstable by strong waves and thus preventing settlement of coral colonies on the bottom and lower part of the spurs' walls which are bare.
Intermediate Level

In this zone, the spurs-and-grooves structures become less marked with increasing depth and, therefore, the differences between the coral communities of the spurs and the grooves tend to disappear. Wave action, though less important than on the upper level, is still the prominent ecological factor of this area; 43 species were collected at $10 \mathrm{~m}$ and 39 at $15 \mathrm{~m}$. The rate of covering of the substratum by the Scleractinia regularly decreases with depth $(45 \%$ at $10 \mathrm{~m}, 40 \%$ at $15 \mathrm{~m}$, $30 \%$ at $20 \mathrm{~m}$ ), whereas the structural level of the community increases $\left(\mathrm{H}^{\prime}=3.76\right.$ bits ind, and $\mathrm{J}^{\prime}=0.69$ at $10 \mathrm{~m}, \mathrm{H}^{\prime}=3.91$ bits ind. and $\mathrm{J}^{\prime}=0.74$ at $15 \mathrm{~m}, \mathrm{H}^{\prime}=$ 4.26 bits ind. and $\mathrm{J}^{\prime}=0.77$ at $20 \mathrm{~m}$ ). The species representing quantitatively more than $50 \%$ of the community are: Pocillopora damicornis forma brevicornis, $P$, verrucosa, Acropora variabilis, $A$. surculosa, Porites (P.) lutea and P. (P.) solida. The encrusting red algae characteristic of the upper level disappear at about $10 \mathrm{~m}$. At this depth, Acropora danai forms a facies similar to that existing on the reef flat with transverse stripes. This species then dominates in the community, covering $60 \%$ of the substratum. Below $15 \mathrm{~m}$, the branched forms are less numerous and replaced by massive colonies, often several meters in diameter at about $15 \mathrm{~m}$ depth. Such supracolonies have been previously observed by Faure and Montaggioni (1971) and Faure (1975) in the Mascarene Archipelago, by Pichon (1973) in Madagascar, Rosen (1971) in the Seychelles islands and Loya and Slobodkin (1971) in the Red Sea.

\section{Lower Level (20 to $25 \mathrm{~m}$ )}

The spurs-and-grooves structure disappears at this level. The coral colonies become sparse (covering rate: 25 to $30 \%$ ) and their size tends to decrease; 46 species were collected. The community is characterized by the appearance of species usually inhabiting deeper waters: Pocillopora damicornis forma caespitosa, Montipora tuberculosa, Montipora sp. 4, Coscinarea monile, Goniopora gracilis, Favites peresi, Goniastrea palauensis, G. pectinata, Platygyra daedalea forma astreiformis, Echinophyllia aspera and Turbinaria irregularis. Nevertheless, the dominant species belong to the spurs-and-grooves community: Pocillopora damicornis forma brevicornis, Astreopora myriophthalma, Porites (P.) lutea and Galaxea fascicularis constitute more than $50 \%$ of the community. In the northern part of the studied reef, the outer slope ends in a sandy field, 15 to $18 \mathrm{~m}$ deep, and this lower level of the community does not exist. 


\section{Community of Lower Sloping Platform and Nodules Field}

The lower sloping platform corresponds to the prelittoral ensemble' of Picard (1967), Clausade et al. (1971), Pichon (1973) and Battistini et al. (1975) and also to the 'morphological zone' of Faure and Montaggioni $(1971,1976)$. Contrary to the community of the spurs-and-grooves area, which is mainly composed of widely distributed species, the coral population of the lower sloping platform and the nodules field is largely constituted by strictly deep-water species: Psammocora explanulata, P. nierstraszi, Stylophora mordax forma compressa, Pocillopora damicornis forma caespitosa, Stylocoeniella guentheri, Acropora granulosa, Montipora subtilis, $M$. vertucosa, Montipora sp. 2, Pavona maldiviensis, Leptoseris fragilis, L. hawaiensis, L. incrustans, Horastrea indica, Cycloseris patelliformis, Herpolitha limax, Goniopora tenuidens, Favia favus, Goniastrea palauensis, Caulastrea tumida, Oulophyllia aspera, Platygyra daedalea forma astreiformis, Hydnophora exesa, Leptastrea bottae, Cyphastrea serailia, Parascolymia sp., Echinophyllia aspera, Gyrosmilia interrupta, Turbinaria irregularis, T. peltata. On the outer slope, both light and wave action decrease with depth. Hence on this reef it is difficult to distinguish among the 'deep water' species true sciaphilic species (e.g. Leptoseris) and those seeking calmer waters (such as Herpolitha limax). The Faviidae dominate the population of this zone, especially Favia speciosa and Favites pentagona. On the whole, the colonies are small and massive or encrusting. The rare branched species (Pocillopora damicornis forma caespitosa, Stylophora mordax forma compressa, Acropora granulosa) exhibit horizontal growth and are table-shaped. The nodules field constitutes a very peculiar substratum, so the community present displays features different from those of the flagstone community.

\section{Lower Sloping Platform}

The rate of covering is low on the flagstone $(20 \%)$ and the colonies are small and scattered. Only the dendrophyllid Turbinaria peltata, a typical species of this zone, forms large colonies. The species richness is the highest of all stations studied (54 species collected). This may seem surprising considering the low vitality of the Scleractinia in this area. However, two facts can explain this phenomenon: first, the lower sloping platform is a sheltered area; secondly, the low coverage rate and the scarcity of the colonies indicate a high degree of space availability and therefore low interspecific competition. The values of the Shannon index $\left(\mathrm{H}^{\prime}=4.67\right.$ bits ind.) and the Pielou evenness index $\left(\mathrm{J}^{\prime}=0.81\right)$ also reveal a high structural level of the community.

Nodules Field

The nodules have been studied by Montaggioni (1978). Their average diameter is about $100 \mathrm{~mm}$ and their density can reach $200 \mathrm{~m}^{-2}$. Montaggioni estimated their age at 400 or $500 y$ and their growth rate

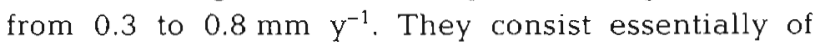
Melobesiae but also of benthic foraminiferans, bryozoans and scleractinians. They are periodically set into motion by very strong cyclonic surges, down to depths of $40 \mathrm{~m}$. Montaggioni estimated that they are turned over every 12 to 18 months. An upper side, colonized by Scleractinia and a lower side occupied by Bryozoa and Serpulidae can generally be recognized. Such nodule formations have already been reported by Faure and Montaggioni (1976) and Faure (1977) in Mauritius Island, as well as in other areas of the Indian Ocean, in Madagascar (Clausade et al., 1971; Thomassin, 1971; Pichon, 1973; Weydert, 1974), and in Aldabra (Barnes et al., 1971). However, until now, only Glynn (1974) and Faure (1977) have described a scleractinian community settled on such a substratum. The instability of this substratum is responsible for the low values of the coral coverage $(2.5 \%)$ and the species richness, the species with a low growth rate being excluded from this zone (54 species on the flagstone, 39 on the nodules field). Nevertheless, the Shannon index $\left(\mathrm{H}^{\prime}=4.4\right.$ bits ind. $)$ and the Pielou evenness index $\left(\mathrm{J}^{\prime}=0.8\right)$ indicate a structural level of the community as high as on the lower sloping platform. This community, similar in its composition to that of the flagstone, could be observed down to $65 \mathrm{~m}$. Only the abundance of Leptoseris increases with depth (Leptoseris fragilis, L. hawaiensis forma tubulifera, $L$. incrustans). Deep communities of Leptoseris have previously been reported by several authors in the Indopacific area (Wells, 1954: Marshall Islands; Loya and Slobodkin, 1971, and Loya, 1972: Gulf of Aqaba; Barnes et al., 1971: Aldabra; Pichon, 1973: Madagascar; Faure, 1977: Mascarene Archipelago). No very deep flagstone could be found on the transect studied but such a substratum exists beyond $50 \mathrm{~m}$ on the northern part of the reef, and a deep community of large gorgonians, antipatharians and sponges was observed, similar to those described by Pichon (1973) in Madagascar and Faure (1977) in other parts of the Mascarene Archipelago. 


\section{DISCUSSION AND CONCLUSIONS}

\section{Structuring of Communities}

Variations in coverage rate by Scleractinia, in species and genera richness, and values of the Shannon and Pielou indices presented in Figure 5, provide information on the general structure of the communities. The degree of coverage, very low in the boat channel, increases on the reef flat seawards. It falls at the level of the surf zone $(0-5 \mathrm{~m})$, thus revealing there the severe ecological conditions and the strong competition with Melobesiae. On the outer slope, coverage reaches a maximum at $10 \mathrm{~m}$ (Station 6) and then decreases to $30 \mathrm{~m}$ (Station 9). The abrupt fall below $30 \mathrm{~m}$ corresponds to the passage to the nodules field. The variations of the species and genera richness are notably parallel. The minimum located on the compact reef flat is related to the facies of Acropora and Pavona. Approximately constant down to $15 \mathrm{~m}$ on the outer slope, the maximum value is reached at $30 \mathrm{~m}$. The passage to the nodules field is also marked by a reduction in species and genera richness. A pronounced decline of the Shannon and the Pielou indices at Stations 2 and 6 resp. is due to the facies of Pavona divaricata and Acropora pharaonis of the compact reef flat and the facies of Acropora danai at $10 \mathrm{~m}$ on the outer slope. The structural level of the community then increases with depth. It must be noted that the coverage rate by Scleractinia and the Shannon index with the Pielou evenness (representative of the degree of structuring of the population) are inversely related. The spurs-and-grooves zone is characterized by a small number of species, well adapted to the local
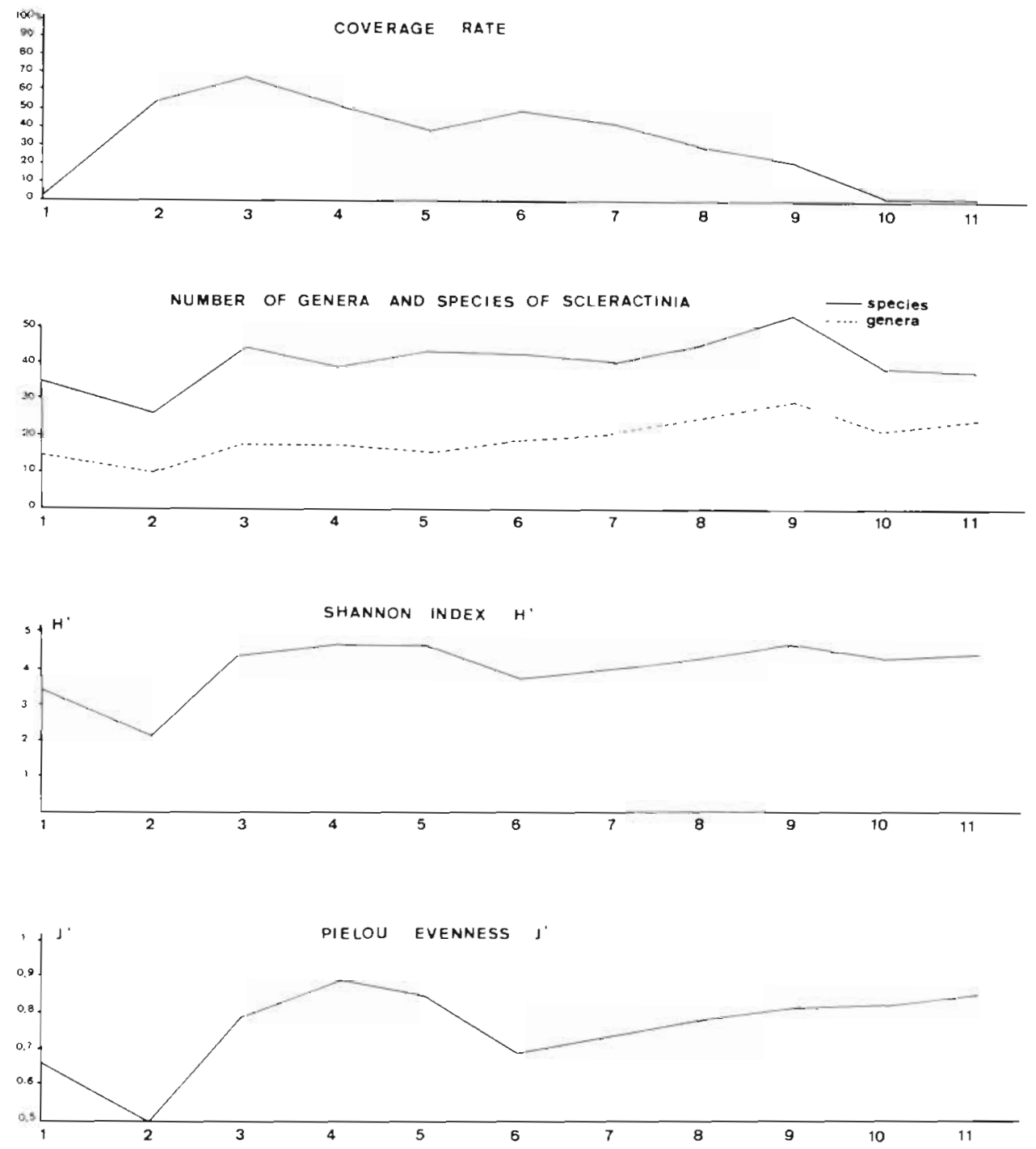

Fig. 5. Variations, along a cross section of the reef, in coverage by the Scleractinia, genera and species richness, Shannon index and Pielou evenness index 


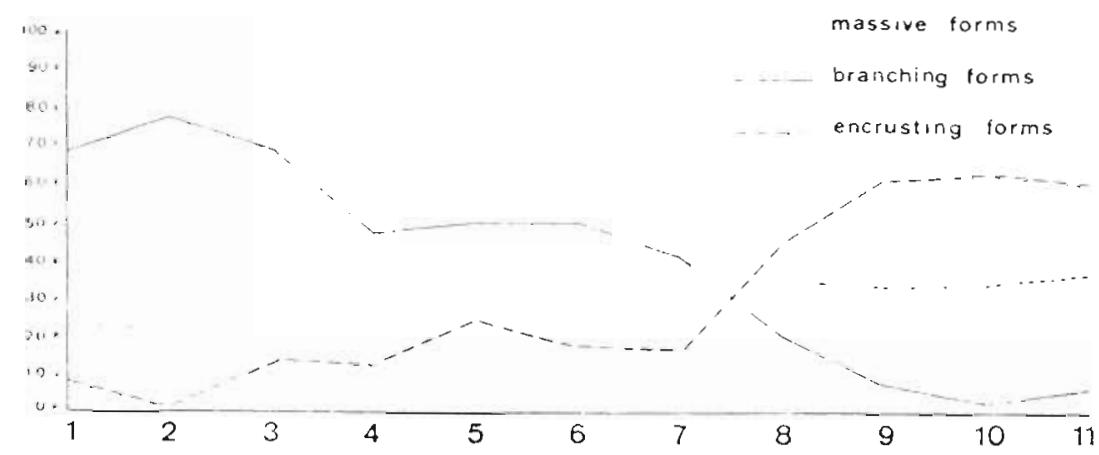

Fig. 6. Proportions of massive, branching and encrusting forms on a cross section of the reef

ecological conditions and with a rapid growth rate, which are responsible for the extension of the reef seawards. Such oppositions between high coral coverage and high specific diversity have previously been mentioned by Loya (1972), Pichon (1973), Maragos (1974) and Faure (1977).

On both sides of this zone, the structuring of the community increases. On the reef studied, the maximum level is reached on the lower part of the outer reef slope. However, several authors have already reported a high degree of structuring of inner reef slopes, located on more highly developed reefs than the one studied (Goreau, 1959, Pichon, 1964, 1973; Laborel, 1967; Faure, 1977). This reveals the importance of sheltered waters and of the homogeneity of ecological factors for the development of a highly structured community (high specific richness, no dominance of a small number of species).

The results concerning the distribution on the reef of the different growth forms (branched, massive or encrusting) are presented in Figure 6. Branched colonies predominate in boat channel and reef flat. On the reef front, they are replaced by massive forms better adapted to strong wave action. For the same reasons, at $5 \mathrm{~m}$ depth, most of the small colonies (massive and even branched ones) are encrusting. Branched colonies represent about $50 \%$ of the growth forms at $15 \mathrm{~m}$. The percentage of massive forms remains approximately constant from 15 to $40 \mathrm{~m}$. On the contrary, the proportions of branching and encrusting forms reverse abruptly between 15 and $30 \mathrm{~m}$. Beyond $30 \mathrm{~m}$, the encrusting forms constitute about $60 \%$ of the colonies, the branching ones only $5 \%$. Thus, branchshaped colonies appear to be poorly adapted to low illumination, as Jaubert (1977) has reported in his study on the ecology of Synarea convexa in French Polynesia. Several other authors have separated, on Indopacific outer reef slopes, an upper level of Pocilloporidae and Acroporidae (branched forms) and a lower level of Porites (massive forms) suggesting a similar distribution (Chevalier et al., 1969; Barnes et al., 1971; Loya and Slobodkin, 1971; Loya, 1972; Rosen, 1971).
The quantitative distribution of the corals provides information on the ecological requirements of certain species. The ability of the Scleractinia to display different requirements depending on the geographical area they inhabit restricts the following remarks to the Mascarene Archipelago. The species were separated in 5 groups:

(1) Species widely distributed on the reef, from the boat channel to the lower part of the outer slope. The most prominent are: Pocillopora damicornis (with different ecological forms), $P$. eydouxi, $P$. verrucosa, Porites (P.) lutea, $P$. (P.) solida and Galaxea fascicularis. It is interesting to point out that the species of this group also possess a very wide geographical distribution.

(2) Species restricted to the outer reef slope. They are not adapted to the ecological conditions of the reef flat and the boat channel (intense illumination, emersion): Astreopora incrustans, A. myriophthalma, Favia speciosa and Favites pentagona.

(3) Photophilic species, tolerant to wave-exposed areas, distributed from the boat channel to the reef front: Psammocora contigua, Acropora pulchra, Porites (P.) nigrescens, P. (Synarea) iwayamaensis.

(4) Photophilic species of sheltered waters, often with fragile growth forms. They are restricted to the boat channel and the compact reef flat: Acropora pharaonis, Montipora circumvallata, Pavona cactus, $P$. decussata, $P$. divaricata, $P$. frondifera, Cyphastrea microphthalma and the Hydrocorallia Millepora exaesa.

(5) 'Deep water' species, including those colonizing the lower sloping flagstone below $20 \mathrm{~m}$ : Psammocora nierstraszi, Acropora granulosa, Astreopora horizontalis, Montipora subtilis, $M$. verrucosa, Leptoseris hawaiensis, $L$. fragilis, $L$. incrustans, Pachyseris speciosa, Coscinarea monile, Horastrea indica, Cycloseris patelliformis, Favites peresi, Caulastrea tumida, Parascolymia sp., Turbinaria peltata.

To these different categories, indicator species can be added: (a) species typical of wave-exposed areas: Acropora palmerae, A. robusta, Favia stelligera, Goniastrea retiformis and the Hydrocorallia Millepora 
platyphylla; (b) species indicatory of moderate wave action: Acropora danai and Millepora tenera.

The different communities are constituted by the grouping of a certain number of these species. The abundance of widely distributed species, as well as the intricacy of different ecological factors, make it difficult to separate the different communities without using quantitative techniques.

\section{Biogeographic Comparisons}

Several authors mentioned the difficulties involved in comparing works concerned with coral communities (Laborel, 1967; Rosen, 1971, 1975; Pichon, 1973; Faure, 1977). The principal problems are the disparity in sampling techniques and the uncertainty of Scleractinia taxonomy. Moreover, if the outer reef slopes generally exhibit a certain number of common features, the inner parts of the reefs are often morphologically and ecologically very different (fringing reefs, barrier reefs, atolls, widths ranging from some $10 \mathrm{~m}$ to several $\mathrm{km}$, presence or absence of boulder tracks, lagoons, seagrass beds) and are, therefore, very difficult to compare.

In Reunion Island, some differences exist between the reef studied and that described by Faure and Montaggioni (1970) and located in the south. The latter, situated in a very exposed area, has an algal ridge and an algal lawn on the reef flat, probably due to the mineral and organic material brought down by a river close to this reef.

There are a few similarities between the coral communities of the inner parts of the reefs of the Mascarene Archipelago (Pichon, 1971; Faure, 1975). Rodriguez Island has an insular platform, about $5 \mathrm{~km}$ wide, which enabled the settlement of a large reef flat, presenting certain similarities with that of Tulear (Madagascar) or Mayotte. The reef flats of Mauritius and Reunion Islands are much alike. However, the narrowness of the Reunion inner reefs does not allow the settlement of sea grass beds in the boat channel, as in the two other islands, where they are of some importance. There is no boulder tract in the Mascarene reefs, except in Rodriguez Island where this formation is only barely apparent (Faure and Montaggioni, 1971; Faure, 1974; Montaggioni, 1978). The important role of such a structure on a reef for water circulation and sediment transportation was outlined by Pichon (1973), Weydert (1973) and Thomassin (1978). In the Mascarene reefs it is not possible to distinguish a community of the outer reef flat and one of the inner reef flat. However, by the similarity of their Scleractinian species composition, the communities of the boat channel and the reef flat of the reef studied and those of the inner reef flat of Tulear reef (Pichon, 1973: Madagascar) can be considered to be analogous.

In the Seychelles Islands, Rosen (1971, 1975) distinguished on the reef flats an 'Acropora assemblage' subjected to wave action and behind, a 'Porites assemblage' in sheltered waters. On the reef studied here, the communities of the compact reef flat and of the reef flat with transverse stripes could correspond to the 'Acropora assemblage'. On the other hand, the narrowness of the reef flat and thus the absence of really sheltered areas could explain the absence of the 'Porites assemblage' on the back reef.

When the reefs are situated in very sheltered zones, as in the Gulf of Aqaba (Red Sea), there is no wellcharacterized zonation of the communities (Loya and Slobodkin, 1971; Loya, 1972; Bouchon, 1979). This enhances the role of a hydrodynamic gradient for the structuring of reef flat communities. In the same way. the importance of the renewal of water for the backreef has been pointed out by several authors in the Pacific Ocean (Chevalier et al., 1969): Mururoa; Maragos, 1974: Fanning Island; Chevalier and Salvat, 1976: Tairao; Maragos and Jokiel, 1976: Canton Island). Maragos and Jokiel (1976) observed a gradient of the specific richness decreasing from the reef to the lagoon center. Chevalier and Salvat (1976) noted the paucity of lagoon communities of totally closed atolls. They all explain this phenomenon by reduced renewal of water and higher rates of sedimentation. Finally, in the Atlantic Ocean, Laborel (1967) and Glynn (1973) described particularly poor reef flat communities with the scleractinian corals restricted by the high abundance of zoantharians and fleshy algae.

The zonation of the communities on the outer slope of the reef studied was defined as a resultant of the decrease of hydrodynamic actions and light, as a function of water depth. This model is applicable to the Mascarene Archipelago (Faure and Montaggioni, 1970, 1971, 1976; Faure, 1977), but also to most of the reefs studied thus far. In Madagascar, Pichon (1964, $1967,1973)$ proposed a distribution of the communities similar to that described here. Barnes et al. (1971) at Aldabra, Rosen (1971) in the Seychelles, Chevalier et al. (1969) in the Pacific, Laborel (1967) and Glynn (1973) for the West Atlantic reefs drew similar conclusions.

The upper level is often characterized as a waveexposed area, except in the Gulf of Aqaba (Loya and Slobodkin, 1971; Loya, 1972; Mergner and Schumacher, 1974; Bouchon, 1979) and the Scleractinia tend to disappear to the benefit of encrusting Corallinacea (Chevalier et al., 1969; Barnes et al.,1971). In the Indian Ocean, algal ridges are rarely developed on the reef front. In accord with Guilcher et al. (1965) and Pichon (1973), it seems that, since the 
works of Wells (1954) in the Marshall Islands, this kind of structure has been generalized too rapidly to pertain to all the reefs under strong wave action. Besides, the abundance of Milleporidae seems everywhere to be a characteristic of the reef front.

Below the upper level, the different authors agree to discern successively, according to the scheme of Rosen (1975), a zone dominated by Acropora and a zone dominated by massive growth forms: Porites zone in the Seychelles and at Eilat (Rosen, 1971; Loya and Slobodkin, 1971); Faviidae zone at Aldabra (Barnes et al., 1971); Montipora zone at Mururoa (Chevalier et al., 1969) and Montastrea zone on the Atlantic reefs (Goreau, 1959; Laborel, 1967). The lower limit of these spurs-and-grooves communities depends on the degree of water transparency in the area considered.

Pichon (1973), Rosen. (1975) and Faure (1977) outlined the scarcity of the data concerning the coral distributions between 25 to $60 \mathrm{~m}$. Wells (1954) distinguished, in the 'deep-water' community of the Marshall Islands, an upper level with Echinophyllia and a lower level with Leptoseris. Some indications on these two zones were also given by Gardiner (1903), in the Maldives, Barnes et al. (1971) in Aldabra, Rosen (1971) in the Indian Ocean, Loya and Slobodkin (1971), Loya (1972) and Bouchon (1979) in the Red Sea. The difficulty to recognize this zonation in Madagascar and in the Mascarene Archipelago led Pichon (1973) and Faure (1977) to gather these 2 levels in a same community of Agariciidae and Pectinidae, characterized in the present study and the South West of the Indian Ocean by the genera Pachyseris and Leptoseris. On the Atlantic reefs, the genus Agaricia seems to play a role similar to that of the genus Leptoseris in the Indopacific area (Goreau and Hartman, 1963; Laborel, 1967; Porter, 1972a).

Pichon $(1971,1973)$ and Faure $(1975,1977)$ pointed out the important Scleractinia species richness of the south west of the Indian Ocean which the predictions of Wells (1954), supported by incomplete data, could not let us foresee. Pichon (1973) found 62 genera in Madagascar and Rosen (1971) mentionned 60 genera in the Maldives, 57 for the Seychelles, 55 at Aldabra and 51 in the Red Sea. Faure (1977) reported 58 genera and 135 species for the whole Mascarene Archipelago. The Mascarene fauna is thus very rich and comparable to the faunas of Madagascar, the Maldives and Seychelles Islands. On the reef studied, 42 genera and 120 species of Scleractinia were identified; this emphasizes the notable faunistic richness of the reef considering the relative narrowness of the back-reef structures.

Acknowledgements. I wish to thank Dr. G. Faure, from Reunion Island University who supervised this work and identified most of the scleractinian corals and Dr. A. Lebeau (I.S.T.P.M. of Reunion Island) for help in accomplishing this research. I also express my thanks to Ms. Diana Walker for revising the English manuscript

\section{LITERATURE CITED}

Barnes, J., Bellamy, D. J., Jones, D. J., Whitton, B. A., Drew, E. A., Kenyon, L., Lythgoe, J. N., Rosen, B. R. (1971). Morphology and ecology of the reef front of Aldabra. Symp. zool. Soc. Lond. 28: 87-114

Battistini, R. (1970). Etat des connaissances sur la géomorphologie de l'île Maurice. Rev. Géogr., Madagascar 17 : 63-37

Battistini, R., Bourrouilh, F., Chevalier, J. P., Coudray, J., Denizot, M., Faure, G., Fisher, J. C., Guilcher, A., Harmelin-Vivien, M., Jaubert, J., Laborel, J., Montaggioni, L., Masse, J. P., Maugé, L. A., Peyrot-Clausade, M., Pichon, M., Plante, R., Plaziot, J. C., Plessis, Y. B., Richard, G., Salvat, B., Thomassin, B. A., Vasseur, P., Weydert, P. (1975). Elements de terminologie récifale indopacifique. Téthys 7 (1): 1-111

Bouchon, C. (1978). Etude quantitative des peuplements à base de Scléractiniaires d'un récif frangeant de l'île de La Reunion (Océan Indien). Thèse 3e cycle Océanographie, Univ. Aix-Marseille 2

Bouchon, C. (1979). Quantitative study of the Scleractinian coral communities of the Jordanian coast (Gulf of AqabaRed Sea): Preliminary results. Téthys 9 (3): 243-246

Chevalier, J. P., Denizot, M., Mougin, J. L., Plessis, Y., Salvat, B. (1969). Etude géomorphologique et bionomique de l'atoll de Mururoa (Tuamotu). Cah. Pacif. 12: 1-144

Chevalier, J. P., Salvat, B. (1976). Etude géomorphologique de l'atoll fermé de Taiaro. Cah. Pacif. 19: 169-201

Clausade, M., Gravier, N., Picard, J., Pichon, M., Roman, M. L., Thomassin, B., Vasseur, P., Vivien, M., Weydert, P. (1971). Morphologie des récifs coralliens de la région de Tuléar (Madagascar): éléments de terminologie récifale. Téthys 2 (Suppl.): $1-74$

Davies, S. P., Stoddart, D. R., Sigee, D. C. (1971). Reef forms of Addu Atoll, Maldives Islands. Sym. zool. Soc. Lond. 28: $217-259$

Dinezen, Z. D. (1977). The coral fauna of the Chagos Archipelago. Proc. 3rd Intern. Coral Reef Symp., Miami 1: $155-161$

Ditlev, H. (1978). Zonation of corals (Scleractinia: Coelentera) on intertidal reef flats at Ko Phuket, Eastern Indian Ocean. Mar Biol. 47: 29-39

Done, T. J. (1977). A comparison of units of cover in ecological classifications of coral communities. Proc. 3rd Intern. Coral Reef Symp., Miami 1: 9-14

Faure, G. (1974). Morphology and bionomy of the coral reef discontinuities in Rodriguez island (Mascarene Archipelago, Indian Ocean). Proc. 2nd Intern. Coral Reef Symp. 1: 161-172

Faure, G. (1975). Etude comparative des récifs coralliens de l'Archipel des Mascareignes (Océan Indien). Mauritius Inst. Bull. 8 (1): 1-25

Faure, G. (1977). Distribution of coral communities on reef slopes in the Mascarene Archipelago, Indian Ocean. Mar Res. Indonesia 17: 73-97

Faure, G., Montaggioni, L. (1970). Le récif corallien de SaintPierre de La Réunion (Océan Indien): géomorphologie et répartition des peuplements. Rec. Trav. Stn mar. Endoume (fasc. hors sér.) 10 (Suppl.): 271-284

Faure, G., Montaggioni, L. (1971). The coral reef of Rodriguez island (Mascarene Archipelago, Indian Ocean): Geomorphology and associated invertebrate communities. Symp. 
on Indian Ocean and adjac. seas, Cochin, abstract 226, sect $21: 143-145$

Faure, G., Montaggioni, L. (1976). Les récifs coralliens auvent de lỉle Maurice (Archipel des Mascareignes, Océan Indien): géomorphologie et bionomie de la pente externe. Mar. Géol. 21: 9-16

Gardiner, J. S. (1903). The Maldive and Laccadive groups, with notes on other coral formations in the Indian Ocean. Fauna and (seogr. Maldive and Laccadive Archipelagoes. 1: $146-183,313-346,376-423$

Glynn, P. W. (1973). Aspects of the ecology of coral reefs in the Western Atlantic Region. In: Jones, O. A., Endean, R. (eds) Biology and geology of coral reefs 1: 271-324

Glynn, P. W'. (1974). Rolling stones among the Scleractinia: Mobile corallith communities in the Gulf of Panama. Proc. 2nd Intern. Coral Reef Symp. 2: 183-198

Goreau, T F. (1959). The ecology of the Jamaican coral reefs (species composition and zonation). Ecology 40 (1): 67-90

Goreau, T. F., Fartman, W. D. (1963). Boring sponges as controlling factors in the formation and maintenance of coral reefs. Publ. Am. Ass. Advmt Sci. 75: 25-54

Guilcher, A., Berthois, L., Le Calvez, Y., Battistini, R., Crosnier, A. (1965). Les récifs coralliens et le lagon de l'île Mayotte. Mém. ORSTOM 11: 1-210 pp

Jaccard, P. (1902). Lois de distribution florale dans la zone alpine. Bull. Soc. Vaudoise Sci. Nat. 38: 69-130

Jaubert, J. (1977). Light, metabolism and growth forms of the hermatypic scleractinian coral Synaraea convexa Verrill in the lagoon of Moorea (French Polynesia). Proc. 3rd Intern. Coral Reef Symp. 483-488

Laborel, J. (1967). Les peuplements de Madréporaires des côtes tropicales du Brésil. Thèse Doct. ès Sciences, Univ. Aix-Marseille 2

Laxton, J. H., Stablum, W. J. (1974). Sample design for quantitative estimation of sedentary organisms of coral reefs. Biol. J. Linn. Soc. 6: 1-18

Loya, Y (1972). Community structure and species diversity of hermatypic corals at Eilat (Red Sea). Mar Biol. 13 (2): $100-123$

Loya, Y (1973). Potless and transect methods. In: Stoddart, D. R., Johannes, R. E. (eds) Coral reefs: Research methods, monogr oceanogr. method. UNESCO, Paris, $581 \mathrm{pp}$.

Loya, Y (1976 a). Effects of water turbidity and sectimentation on the community structure of Puerto Rican corals. Bull. mar Sci. 26 (4): 450-466

Loya, Y. (1976 b). Recolonization of Red Sea corals affected by natural catastrophies and man-made perturbations. Ecology 57 (2): 278-289

Loya, Y., Slobodkin, L. (1971). The coral reefs of Eilat (Gulf of Eilat, Red Sea). Symp. zool. Soc. Lond. 28: 117-140

Maragos, M. (1974). Coral communities on a seaward reef slope, Fanning Island. Pacif. Sci. 28 (3): 257-278

Maragos, J. E., Jokiel, P. L. (1976). Reef corals of Canton Atoll: 2 - local distribution. In: An environmental survey of Canton Atoll lagoon, 1973. Naval Undersea Research. NCV. 395, $192 \mathrm{pp}$.

Mergner, H., Schumacher, H. (1974). Morphologie, Okologie und Zonierung von Korallenriffen bei Aqaba (Golf von Aqaba, Rotes Meer). Helgolander wiss. Meeresunters. 26: $238-358$

Montaggion, L. (1974). Coral reefs and quaternary shore Iines in the Mascarene Archipelago (Indian Ocean). Proc. 2nd Intern. Coral Reef Symp. 2: 579-593

Montaggioni, L. (1978). Recherches géologiques sur les complexes récifaux de l'Archipel des Mascareignes (Océan Indien Occidental). Thèse Doct. ès Sciences, Univ, AixMarseille 2
Morton, J. (1974). The coral reefs of the British Salomon Islands; A comparative study of their composition and ecology. Proc. 2nd Intern. Coral Reef Symp. 2: 31-54

Neudecker, S. (1976). Effects of thermal effluent on the coral community at Tanguisson. Univ, Guam., Mar. Lab, techn. Rep. 30: 1-55

Ott, B., Auclair, A. N. (1977). Cluster analytic definition of speriz's ecological group for a submerged Barrier reef in Barbados, West Indies. Int. Revue ges. Hydrobiol. 62 (1): $41-51$

Picard. J. (1967). Essai de classement des grands types de peuplements marins benthiques tropicaux, daprès les observations effectuées dans les parages de Tulear (Sud Ouest de Madagascar). Rec. Tray. Stn mar. Endoume (fasc. hors sér.) 6 (Suppl.): 3-24

Plchon, M. (1964). Contribution à l'étude de la répartition des Madréporaires sur le récif de Tuléar (Madagascar). Rec. Trav. Stn mar. Endoume (fasc. hors sér.) 2 (Suppl.): 79-203

Pichon, M. (1971). Comparative study of the main features of some coral reefs of Madagascar, La Réunion and Mauritius. Symp. zool. Soc. Lond. 28: 185-216

Pichon, M. (1973). Recherches sur les peuplements à dominance d'Anthozoaires dans les récifs coralliens de Tuléar (Madagascar). Thèse Doct. ès Sciences, Univ. Aix-Marseille 2

Porter, J. W (1972 a). Patterns of species diversity in Caribbean reef corals. Ecology 53 (4): 745-748

Porter, J. W. (1972 b). Ecology and species diversity of coral reefs on opposite sides of the Isthmus of Panama. Bull Biol, Soc. Wash. 2: 89-116

Rıbes, S. (1978). La macrofaune vagile associée à la partie vivante des Scléractiniaires sur un récif frangeant de l'ìle de La Réunıon. Thèse 3ème cycle Océanologie, Univ. AixMarseille

Rosen, B. R. (1971). The distribution of reef coral genera in the Indian Ocean. Symp. zool. Soc. Lond. 28: 263-300

Rosen, B. R. (1975). The distribution of reef corals. Underwater Ass. (N. S.) 1975: 1-16

Salvat, B., Richard, G., Salvat, F., Berigaud, R., Antoine, L., Berigaud, M. C., Plessis, Y (1972). Moorea-Tiahura: Etude des peuplements du lagon et du récif. Rapp et $C$. R. des recherches réalisées par l'antenne de Tahiti du Mus. Nat. Hist. nat. 1972: 1-144

Sanders, H. L. (1969). Benthic marine diversity and the stabiltty-time hypothesis, In: Diversity and stability in ecological systems. Brookhanen Symposia in Biology 22: 71-81

Stoddart, D. R. (1971). Problems and prospect in Indian Ocean reef studies. Symp. zool. Soc. Lond. 28: 549-553

Thomassin, B. (1971). Les faciès d'épifaune et d'épiflore des biotopes sédimentaires des formations coralliennes dans la région de Tulear (Sud-Ouest de Madagascar) Symp. Lool. Soc. Lond. 28: 371-376

Thomassın, B. (1978). Peuplements des sédiments coralliens de la région de Tuléar (Sud Ouest de Madagascar), leur insertion dans le contexte cótier Indo-Pacifique. Thèse Doct ès Sciences, Univ. Aix-Marseille 2

Wells, J. W. (1954). Recent corals of the Marshall islands. Prof. Pap. U.S. geol. Surv. 260 (1): 385-486

Weydert, P. (1973). Morphologie et sédimentologie des formations récifales de la région de Tuléar (Sud Ouest de Madagascar). Thèse Doct ès Sciences, Univ. Alx-Marseille 2

Weydert, P. (1974). Morphologie et sédimentologie de la pente externe de la partie nord du Grand Récif de Tuléar (Sud Ouest de Madagascar). Nature et répartition des éléments organogènes libres. Mar. Géol. 17 (5): 299-337 